\title{
The demarcation and internal division of Flora Malesiana: 1857 - present
}

\author{
N. Raes ${ }^{1}$, P.C. van Welzen ${ }^{1}$
}

Published on 30 October 2009

\section{FLORA MALESIANA}

The Malesian region as we know it and are using to finish one of the world's most prestigious flora projects is generally thought to have been defined by Van Steenis $(1948,1950)$. He indeed circumscribed the area, but the term 'Flora Malesiana' is older. This name was introduced by Zollinger (1857). Few people know this and generally they refer to an incorrect publication, which can easily be explained by the fact that Zollinger's article is in Dutch and, therefore, unreadable for most inhabitants of our planet. All the more reason to put the spotlight on Zollinger in these proceedings of the seventh Flora Malesiana Symposium and elucidate the background of the term 'Malesiana'.

The Malesian floristic region was first recognized and described by the Swiss botanist and explorer Heinrich Zollinger in 1857 (Zollinger 1857, Johns 1995). In his publication, Zollinger (1857) comments on the demarcation of the 'Flora of the Dutch Indies' by Miquel (1855-1859), and argues that a floristic region should not be confused with the boundaries of a country's colonies. Based on a very limited number of distribution data and with mainly straight lines, Zollinger (1857) defined the boundaries of the Malesian floristic region (Fig 1, total grey area). He named his floristic region Flora Malesiana, after the common use of the Malay language throughout the entire Archipelago. For colleagues at the time, who found the delimitation too extensive, Zollinger (1857) even recognized a 'Flora Malesiana' in a more restricted sense (Fig. 1, dark-grey area). He acknowledged that the western peninsular Malesia probably should be split up into three different regions: a northern-, central-, and southern region. According to Zollinger the southern region definitely belonged to the Malesian floristic region, and indeed this boundary corresponds with one of the demarcation knots of Van Steenis (1948, 1950; see below) . $\mathrm{He}$ argued that it seemed most natural that the most northern boundary of the restricted Malesian floristic region ran from the Andaman Islands, through Salanga Island (= Phuket), via the Phun-Phin bay and Poeloe Oebi to Balabac Island, north of Borneo; and from there to Cape d'Urville on New Guinea. He excluded most of New Guinea from the Malesian flora due to lack of collections, and the reported sightings of snow-covered mountain peaks. This led him to conclude that the flora of New Guinea likely resembled that of a temperate mainland more than that of an island flora, hence New Guinea was largely excluded from the floristic region.

Almost a century later, Van Steenis largely confirmed the Malesian floristic boundaries of Zollinger's initial delimitation, based on distribution maps of 2178 genera (Van Steenis 1948, 1950). This work was a continuation of the physiognomic map

\footnotetext{
1 National Herbarium of the Netherlands, Leiden University, P.O. Box 9514, 2300 RA Leiden, The Netherlands;

corresponding author e-mail: raes@nhn.leidenuniv.nl
}

of the Dutch East Indies colonies, currently known as Indonesia, which he published in 1935 (Van Steenis 1935a, b). Van Steenis identified four contact zones and three principal 'demarcation knots' of Malesia with adjacent floral regions, viz. between the Malay Peninsula (e.g. the very south of Thailand) and Asia, between the Philippine Islands and Taiwan, the Torres Strait between New Guinea and Australia, and a less clear contact zone between the Bismarck- and Solomon islands and the Pacific islands (Van Steenis 1950). The latter was arbitrarily taken as eastern border because of lack of data (Fig. 1). The natural eastern boundary of the region lies in fact east of the Pacific Islands (Van Balgooy et al. 1996). It should also be noted that the demarcation knot between the Malay Peninsula and Asia is not located at the Isthmus of Kra, but through the southernmost provinces of Thailand (Van Steenis 1950). This boundary more or less corresponds with the demarcation of the southern region of the western peninsular Malesia mentioned by Zollinger (1857). The phytogeographical status of the Malesian floristic region was recently confirmed by Van Welzen et al. (2005), who found that $70 \%$ of 6616 sampled species was endemic to Malesia.

\section{Wallace's Line, the Sunda Shelf, Wallacea, and the Sahul Shelf}

Ever since the first recognition of Malesia as a floristic region, a debate is going on about its internal subdivision. The most famous division is in a western and eastern sub-region, separated by Wallace's Line (Fig. 1; Wallace 1860). Wallace (1860) found a distinct boundary between the Southeast Asian- and the New Guinean-Australian fauna, located east of the Philippines, between Borneo and Sulawesi and finally between Bali and Lombok. Other authors have recognized similar lines, or western and eastern variants of Wallace's Line (Fig. 1). A recent study of the evidence of the different lines based on botanical records of 6616 species showed that for all lines on each side twice as many, or far more, species stop than cross the lines, and that the lines become stronger from west to east, meaning that less species cross the more eastward lines (Van Welzen et al. 2005). The strong boundary of the eastern Lydekker's line indicates the very different nature of the New Guinean flora. This finding was also supported by the Principal Coordinates Analysis on a slightly larger dataset containing data of 7043 species, showing the separate position of New Guinea (Fig. 2) (Van Welzen \& Slik 2009). Note that the Merrill-Dickerson/ Huxley Line actually includes Java with Borneo, Sumatra, and the Malay Peninsula (explained below).

A floristic separation in three regions corresponds very closely with the geological history of the Malay Archipelago (Hall 1998, Van Welzen \& Slik 2009). The western part, west of the MerrillDickerson/Huxley Line in Fig. 1, including Borneo, Sumatra, the

(c) 2009 Nationaal Herbarium Nederland

You are free to share - to copy, distribute and transmit the work, under the following conditions:

Attribution: $\quad$ You must attribute the work in the manner specified by the author or licensor (but not in any way that suggests that they endorse you or your use of the work).

Non-commercia:

You may not use this work for commercial purpose

No derivative works: You may not alter, transform, or build upon this work.

For any reuse or distribution, you must make clear to others the license terms of this work, which can be found at http://creativecommons.org/licenses/by-nc-nd/3.0/legalcode. Any of the above conditions can be waived if you get permission from the copyright holder. Nothing in this license impairs or restricts the author's moral rights. 


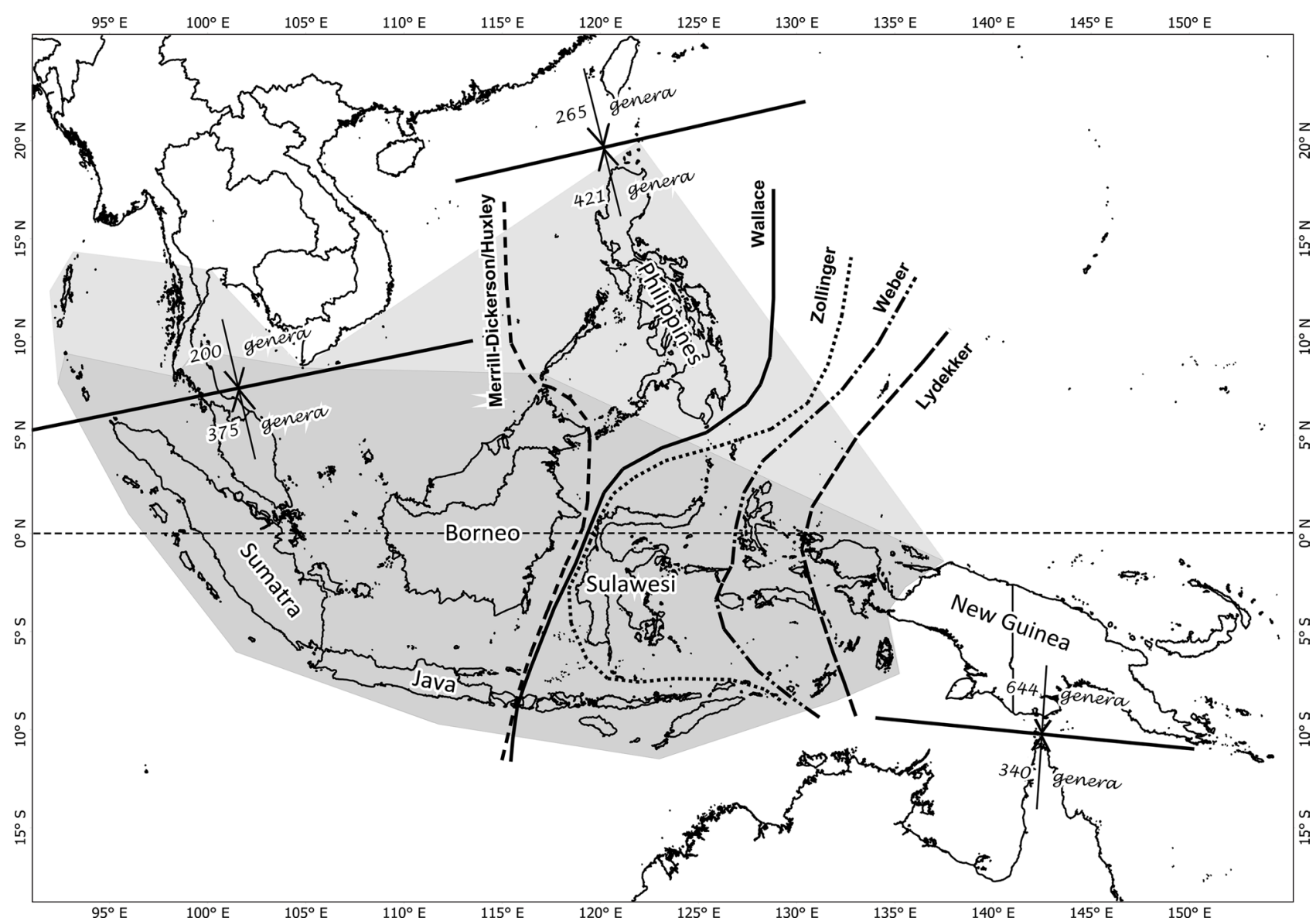

Fig. 1 The boundaries of the Malesian floristic region defined by Zollinger (1857) in the widest sense (total grey area) and in the more restricted sense (dark-grey area); and the delimitation by Van Steenis $(1948,1950)$ indicated by the three demarcation knots. The numbers indicate the number of genera not crossing the knots. The different lines indicate Wallace's Line and the eastern and western variants by different authors.

Malay Peninsula, and Java is also known as the Sunda Shelf. This continental shelf formed one continuous landmass during glacial maxima, when the sea levels were $\sim 120$ m lower than at present, caused by an increase in land ice on the polar caps (Voris 2000, Bird et al. 2005). Under these conditions species were able to disperse to other areas on the Sunda Shelf. This has resulted in relatively high similarities between the floras of the different islands on the Sunda Shelf (Fig. 2 filled squares). Java is an exception, as it is - in contrast to the everwet other islands on the Sunda Shelf - for a large part of its surface characterized by a dry monsoon climate (Van Steenis 1979). Hence, it clusters with the islands of central Malesia, which have similar climatic conditions (Fig. 2 diamonds). This central

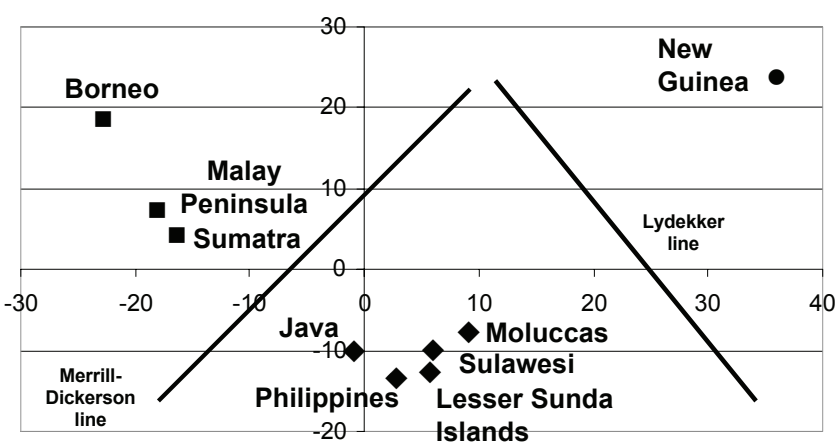

Fig. 2 Results of the Principal Coordinates Analysis (PCO) based on presence/absence data of 7043 plant species for the nine island groups of the Malay Archipelago. $\mathbf{\square}=$ everwet areas on the Sunda shelf; $\boldsymbol{\nabla}=$ seasonally dry areas; $=$ everwet areas on the Sahul shelf. Adapted from Van Welzen \& Slik 2009: f. 1 a.
Malesian region is known as Wallacea, and is located between the Merrill-Dickerson/Huxley- and Lydekker's Line. Like the continental Sunda Shelf, this central Malesian region consists of microplates which have remained submerged, only to emerge after they collided, which for Sulawesi happened only 15-10 Ma (Hall 1997, 1998, Van Welzen et al. 2005). Hall (1997, 1998, 2009) provides a comprehensive overview of how the different microplates and continental platelets of Wallacea have moved, collided, emerged and submerged during the last $50 \mathrm{Ma}$.

The absence of land bridges in Wallacea disconnected the western Sunda Shelf from the eastern part of Malesia, the Sahul Shelf, also known as Papuasia (Johns 1995). Like the Sunda Shelf, the eastern Sahul Shelf is a continental shelf which connected New Guinea to Australia during glacial maxima. The separation from the western Sunda Shelf from the eastern Sahul Shelf by Wallacea has resulted in a distinct floristic composition on both shelves (Fig. 2; Van Welzen \& Slik 2009).

\section{REFERENCES}

Bird MI, Taylor D, Hunt C. 2005. Palaeoenvironments of insular Southeast Asia during the last glacial period: a savanna corridor in Sundaland? Quaternary Science Reviews 24: 2228-2242.

Hall R. 1997. Cenozoic plate tectonic reconstructions of SE Asia. In: Fraser AJ, Matthews SJ, Murphy RW (eds), Petroleum geology of Southeast Asia: 11-23. The Geological Society, London.

Hall R. 1998. The plate tectonics of cenozoic SE Asia and the distribution of land and sea. In: Hall R, Holloway JD (eds), Biogeography and geological evolution of SE Asia: 99-131. Backhuys Publishers, Leiden, The Netherlands.

Hall R. 2009. Southeast Asia's changing palaeogeography. Blumea 54: $148-161$. 
Johns RJ. 1995. Malesia - An introduction. Curtis's Botanical Magazine 12: $52-62$.

Miquel FAW. 1855-1858. Flora van Nederlandsch Indië 1, 1. Van der Post, Amsterdam.

Miquel FAW. 1959, 1859. Flora van Nederlandsch Indië 1, 2. Van der Post, Amsterdam.

Miquel FAW. 1856-1858. Flora van Nederlandsch Indië 2. Van der Post, Amsterdam.

Miquel FAW. 1855-1859. Flora van Nederlandsch Indië 3. Van der Post, Amsterdam.

Van Balgooy MMJ, Hovenkamp PH, Van Welzen PC. 1996. Phytogeography of the Pacific - floristic and historical distribution patterns in plants. In: Keast A, Miller SE (eds), The origin and evolution of Pacific Island biotas, New Guinea to eastern Polynesia: patterns and processes: 191-213. SPB Academic Publishing, Amsterdam, The Netherlands.

Van Steenis CGGJ. 1935a. Maleische vegetatieschetsen I; Toelichting bij de plantengeografische kaart van Nederlandsch Oost Indië. Tijdschrift van het Koninklijke Nederlandse Aardrijkskundige Genootschap 52: 25-67.

Van Steenis CGGJ. 1935b. Maleische vegetatieschetsen II. Tijdschrift van het Koninklijke Nederlandse Aardrijkskundige Genootschap 52: 171-203, 365-398.
Van Steenis CGGJ. 1948. Hoofdlijnen van de plantengeografie van de Indische archipel op grond van de verspreiding van de Phanerogamen geslachten. Tijdschrift van het Koninklijke Nederlandse Aardrijkskundige Genootschap 65: 193-208.

Van Steenis CGGJ. 1950. The delimitation of Malaysia and its main plant geographical divisions. Flora Malesiana, Ser. I, Vol. 1: Ixx-Ixxv.

Van Steenis CGGJ. 1979. Plant-geography of east Malesia. Botanical Journal of the Linnean Society 79: 97-178.

Van Welzen PC, Slik JWF. 2009. Patterns in species richness and composition of plant families in the Malay Archipelago. Blumea 54: 166-171.

Van Welzen PC, Slik JWF, Alahuhta J. 2005. Plant distribution patterns and plate tectonics in Malesia. Biologiske Skrifter 55: 199-217.

Voris HK. 2000. Maps of Pleistocene sea levels in Southeast Asia: shorelines, river systems and time durations. Journal of Biogeography 27 1153-1167.

Wallace AR. 1860. On the zoological geography of the Malay Archipelago. Journal of the Linnean Society of London 4: 172-184.

Zollinger H. 1857. Over het begrip en den omvang eener Flora Malesiana. Natuurkundig Tijdschrift voor Nederlandsch-Indië 13: 293-322. 